\title{
Application of Theory of Planned Behavior for Knowledge Sharing System Among Nurses
}

\author{
Annisa SEPTIANI ${ }^{1}$, Rahmat Izwan HEROZA ${ }^{2 *}$, Dwi Rosa INDAH ${ }^{3}$, Rizki Dwi \\ $\mathrm{CAHYANI}^{4}$ and Niffari Meirina BERNOVA ${ }^{5}$
}

\author{
${ }_{1,2,3,4,5}$ Faculty of Computer Science, Universitas Sriwijaya, Indonesia \\ *Corresponding author : rahmatheroza@unsri.ac.id
}

\begin{abstract}
Nurses play an important role in the hospital because they give services and care to the patients. The world of health is increasingly developed, demanding nurses to keep adding and equalizing their knowledge, while they are still doing their job. So, it is necessary to share knowledge between nurses so that nurses can keep adding their knowledge and share their knowledge and experience they have to their colleagues. This research uses the Theory of Planned Behavior to search the factors that affect nurses' intention to share knowledge. The factors consist of the Theory of Planned Behavior's variables namely intention, subjective norm, perceived behavioral control, and attitude. Those variables are been analyzed and the results are used to determine what motivations that can affect nurses' intention to share knowledge. These motivations are then used to propose a set of features of Knowledge Management System that can be adopted by nurses to share their knowledge among them.
\end{abstract}

Keywords: Theory of Planned Behavior, knowledge sharing, nurse, hospital

\section{Introduction}

Nurses give service and care to patient all the time and are required to possess knowledge and expertise to enhance the result of health care and bring forward the health promotion (Sundean, White, Thompson, \& Prybil, 2019). Diverse condition of the patients such as cultural diversity (Lin, Wu, \& Hsu, 2019) can degrade the care quality. On the other hand, different nurses can have different experiences in a certain area (Gjesdal, Dysvik, \& Furnes, 2019; Hajia, Mohammed, Al-Saqer, Kamel, \& El-Shazly, 2011; Phetlhu, Bimerew, Marie-Modeste, Naidoo, \& Igumbor, 2018). Thus they need to share knowledge among them (Lee \& Hong, 2014; Shaari, Bakri, \& Mannan, 2015). By sharing the knowledges, it is expected to create equalization of the ability of nursing and service and therefore it will decrease mistakes of treatment that frequently made by nurses (Harrison et al., 2015).

The focus of knowledge management is how to share knowledge to create profit of value to the organization (Liebowitz, 2001). Knowledge sharing, which is part of knowledge management, is a process by which individuals are willing to share the knowledge they have in tacit or explicit to other colleagues (King, 2006). Knowledge sharing has many impacts for the organization such as increasing organizational performance (Oyemomi, Liu, Neaga, Chen, \& Nakpodia, 2019) and job satisfaction (Trivellas, Akrivouli, Tsifora, \& Tsoutsa, 2015). In this case, we may relate knowledge sharing to a psychological process that requires a series of initiative to help employees identify the knowledge they possess and then to motivate, enable and encourage them to share that knowledge with others (Ipe, 2003).

But, it's not easy to make a group of people in an organization to share their knowledge. There are many factors not only individuals such as peer recognition (Leal, Cunha, \& Couto, 2017) and rewards (Šajeva, 2014) but also organizational such as knowledge sharing culture in the organization (Kathiravelu, Mansor, T.Ramayah, \& Idris, 2014). That is why, this paper will try to find factors that affect nurse's intention to share knowledge using the Theory of Planned Behavior, which has been widely used to predict human behavior.

Some researches has been using TPB to explore knowledge sharing activities such as research from (Ryu, Ho, \& Han, 2003) which predicts physician's behavior in the hospital using a combination of TRA and TPB. Then, research from (Samad, 2018) which examined the effect of distributive justice on the relationship between TPB and knowledge sharing activity among nurses. And also research from (Jambak, 2017) which predict factors that affect knowledge sharing behavior among students.

In this research, we will use TPB's variables such as attitude, subjective norm, perceived behavioral control and intention to share knowledge. Those variables will be examined using the PLS method. According to (Ghozali, 2014), PLS is an alternative approach that shifts from a covariant-based SEM approach to variant based.

After we got factors that affect nurses to share their knowledge, it will be implemented in the form of features of a knowledge sharing system.

\section{Methodology}

This research was conducted using descriptive analysis method using questionnaires distributed to research respondents.

\section{Research Model}

In this study the research model used originated from the Theory of Planned Behavior model where the theory explains that one's intention is determined by factors such 


\section{Population and Sample}

as attitudes, subjective norms and perceived behavioral control.

Based on the theory, there are 2 dependent variables (X) and 2 independent variables $(\mathrm{Y})$ :

- $\quad$ Subjective norms (X1) indicators :

○ I will share my knowledge if my colleagues do that too (X11)

- I will be on discussion forum if I'm interested with the (X12)

- I will be on discussion forum if my colleagues on that forum too (X13)

○ Perceived Behavioral Control (X2) indicators :

- I have knowledge to share (X21)

- Online media make it easier to share knowledge (X22)

- If I share my knowledge, I want to get positive response (X23)

$\circ$ Getting reward will increase my enthusiasm in sharing knowledge (X24)

- $\quad$ Attitude (Y1) indicators :

- I like knowledge sharing (Y11)

- I feel the benefit of sharing knowledge (Y12)

- With knowledge sharing we can get new knowledge (Y13)

- I like sharing knowledge through online media (Y14)

- Easier to search knowledge(Y15)

○ (Y16)

- I want feedback (such as comment and like) if i sharing knowledge (Y17)

$\circ \quad$ I will give feedback if my colleagues share their knowledge (Y18)

$\circ$ (Y19)

- Intention (Y2) indicators :

- I intend to share knowledge (Y21)

- I intend to help my colleagues with knowledge sharing(Y22)

○ I want my knowledge useful for my colleagues(Y23)

○ I will share my knowledge with my colleagues if they ask (Y24)

- I want to get knowledge from my colleagues (Y25).

Each variable was tested with research questions using a Likert Scale model. For the analysis of the answers, we use the PLS method and SmartPLS software.

Based on the TPB, we offer the hypotheses concerning the nurse's knowledge sharing intention :

$\mathrm{H} 1$ : It is suspected that there is influence from the Attitude towards the Intention of knowledge sharing.

$\mathrm{H} 2$ : It is suspected that there is influence from the Subjective Norm towards the Intention of knowledge sharing.

$\mathrm{H} 3$ : It is suspected that there is influence from the Perceived Behavioral Control towards the Intention of knowledge sharing.

$\mathrm{H} 4$ : It is suspected that there is influence from the subjective norm towards the Attitude of knowledge sharing.
As the case study, we examine Siti Khadijah Hospital in the city of Palembang. Data are collected in two ways, namely:

1. Pilot questionnaire test. The pilot questionnaire was conducted to elicit salient beliefs of samples. After getting the results of the pilot questionnaire, a final questionnaire will be made from items obtained from the results of the pilot questionnaire. Pilot questionnaire given to 7 respondent who were representative of each division. The results of the pilot questionnaire will determinine indicators on the final questionnaire.

2. Survey by given final questionnaire which indicators are the results of pilot questionnaire. Research population was 198 people. Research sample are calculated using Slovin formula:

$n=\frac{N}{1+N e^{2}}$

Where :

$$
\begin{aligned}
\mathrm{n} & =\text { Sample Size } \\
\mathrm{N} & =\text { Sample Measurement } \\
\mathrm{e} & =\text { Error Rate }(5 \%) \\
n & =\frac{198}{1+198(0.05)^{2}} \\
& =132,44 \text { rounded } 132
\end{aligned}
$$

Based on results of the calculation, it was found that the number of samples needed was 132 nurses at Siti Khadijah Hospital Palembang.

\section{RESULTS AND DISCUSSION}

\section{Validity Test}

Validity test is used to measure the validity of a questionnaire (Ghozali, 2014) $\square$. Validity test used loading factor from SmartPLS software calculation. 
Figure 1 Structural Model of Origin Data

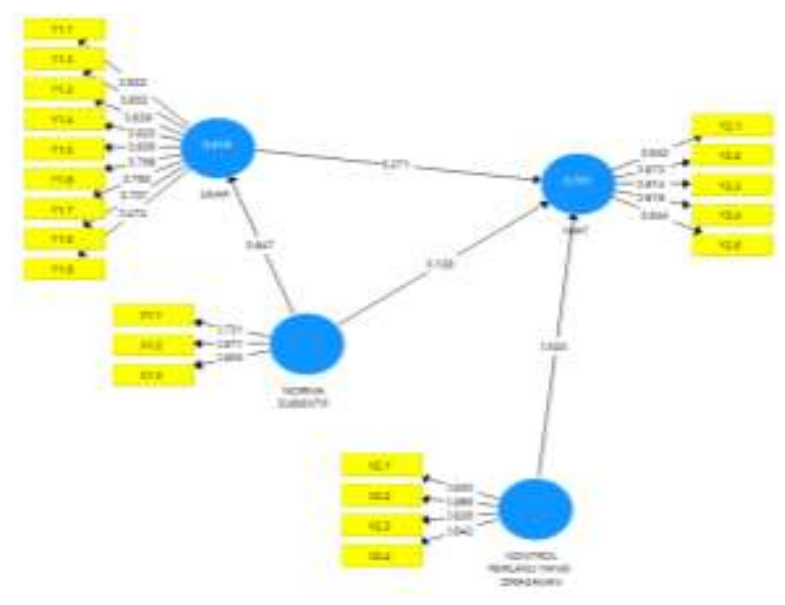

In indicator Y1.9, the outer loading value is $<0,5$ so it is need to be reducted. While other indicators from each variable are accepted. The process of reducing the indicator has been done one by one sequentially per variable starting from the indicator with the smallest loading factor, until all question items meet the recommended value (Picture 2).

Table 1. Composite Reliability dan AVE
Outer Model value is calculated by looking at the value of Convergent Validity, that is when the value of Loading Factor $>0.70$, it means that the indicator is highly recommended. While for values $>0.50-0.60$, the indictor can still be tolerated as long as the model is still under development.

\section{Reliability Test}

Reliability test is how much degree of test consistently measures the target. Testing is done by looking at Composite Reliability that is generated by the calculation of SmartPLS software from existing variables : Attitude (Y1), Subjective Norm (X1), Perceived Behavioral Control (X2), dan Intention (Y2). Composite Realibility value that reliable is $\boldsymbol{\rho}_{C} \geq 0.70$ and Average Variance Extracted $(\mathrm{AVE})>0.50$.

The results of reliability test for all variables which calculated are shown in Table 1. From the results of the reliability test, it shows that all research variables have been shown to be fit gauges. In general, the variables studied from all items of questions to be used have a good level of reliability.

\begin{tabular}{|c|c|c|}
\hline Variable & $\begin{array}{c}\text { Composite } \\
\text { Reliability }\end{array}$ & $\begin{array}{c}\text { Average Variance } \\
\text { Extracted (AVE) }\end{array}$ \\
\hline $\begin{array}{c}\text { Perceived } \\
\text { Behavioral } \\
\text { Control }\end{array}$ & 0.908 & 0.712 \\
\hline Intention & 0.911 & 0.677 \\
\hline $\begin{array}{c}\text { Subjective } \\
\text { Norm }\end{array}$ & 0.861 & 0.675 \\
\hline Attitude & 0.924 & 0.581 \\
\hline
\end{tabular}

\section{Structural Model Test (Inner Model)}

Inner model testing is done to see the relationship between variables from the research model as the structural model is evaluated using R-square (coefficient of determination) for the dependent variable.

The higher the R-square value, the greater the ability of the independent variable to explain the dependent variable so that the structural equation is better.

Table 2. R-Square

\begin{tabular}{|c|c|}
\hline Variable & R-Square \\
\hline$(1)$ & $(2)$ \\
\hline Attitude (Y1) & 0,419 \\
\hline Intention (Y2) & 0,701 \\
\hline
\end{tabular}

Table 2 shows the results of the R-square of intention is 0.701 , which means that variability of intention can be explained by the attitude, subjective norms and perceived control by $70.1 \%$, while the remaining $29.9 \%$ is determined by other factors.

Table 2 also shows the results of the R-Square of Attitude is 0.419 , which means that variability of attitude can be explained by Subjective Norm by $41,9 \%$, while the remaining $58,1 \%$ is determined by other factors.

\section{Hypothesis Test}

Hypothesis testing is based on the values found in the analysis of structural models. The limit of the value of hypothesis testing, namely the t-value is greater than the critical value $(\geq 1.98)$. 
Table 3. T statistics and P Values

\begin{tabular}{|c|c|c|}
\hline & $\begin{array}{c}\text { T Statistics } \\
(|\mathrm{O} / \mathrm{STDEV}|)\end{array}$ & P Values \\
\hline Attitude -> Intention & 2.486 & 0.013 \\
\hline Subjective Norm -> Intention & 1.08 & 0.28 \\
\hline $\begin{array}{c}\text { Perceived Behavioral Control } \\
->\text { Intention }\end{array}$ & 6.288 & 0.000 \\
\hline Subjective Norm -> Attitude & 8.717 & 0.000 \\
\hline
\end{tabular}

The results of the hypothesis (Picture 3, Picture 4) are obtained as follows.

First hypothesis : Attitude affects the Intention. The results of the $t$ statistics is $2.486(\geq 1.98)$ and $p$-value is $0.013(<0.025)$. It is concluded that Attitude give a significant influence towards Intention.

Second hypothesis : Subjective Norm affects the Intention. The results of the t statistics is $1.08(\leq 1.98)$ and p-value is $0.23(>0.025)$. Thus, it is concluded that Subjective Norm did not give influence toward Intention.
Third hypothesis : Perceived Behavioral Control affects the Intention. The results of the $t$ statistics is $6.288(\geq$ $1.98)$ and $p$-value is $0.000(<0.025)$. It is concluded that Perceived Behavioral Control give a significant influence towards Intention.

Forth hypothesis : Subjective Norm affects the Attitude. The results of the $t$ statistics is $8.717(\geq 1.98)$ and $p$-value is $0.000(<0.025)$. It is concluded that Subjective Norm gives a significant influence towards Attitude.

Table 4. Hypothesis Results

\begin{tabular}{|c|c|c|}
\hline No & Hypothesis & Result \\
\hline H1 & $\begin{array}{c}\text { It is suspected that there is influence from the Attitude } \\
\text { towards the Intention of knowledge sharing. }\end{array}$ & Accepted (Significant ) \\
\hline H2 & $\begin{array}{c}\text { It is suspected that there is influence from the } \\
\text { Subjective Norm towards the Intention of knowledge } \\
\text { sharing. }\end{array}$ & Rejected \\
\hline H3 & $\begin{array}{c}\text { It is suspected that there is influence from the Perceived } \\
\text { Behavioral Control towards the Intention of knowledge } \\
\text { sharing. }\end{array}$ & Accepted (Significant ) \\
\hline H4 & $\begin{array}{c}\text { It is suspected that there is influence from the subjective } \\
\text { norm towards the Attitude of knowledge sharing. }\end{array}$ & Accepted (Significant ) \\
\hline
\end{tabular}

\section{Direct, Indirect, dan Total Effect}

Table 5. Direct Effect

\begin{tabular}{|c|c|c|c|c|}
\hline Variable & 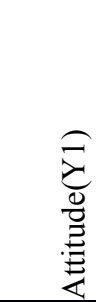 & 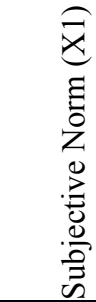 & 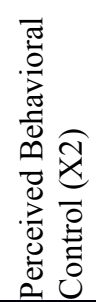 & 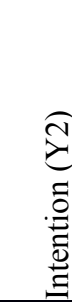 \\
\hline $\begin{array}{l}\text { Attitude } \\
\text { (Y1) }\end{array}$ & - & 0.647 & - & - \\
\hline $\begin{array}{l}\text { Intention } \\
\text { (Y2) }\end{array}$ & 0.271 & 0.128 & 0.524 & - \\
\hline
\end{tabular}

For the Intention (Y2), it can be seen in Table 5 that from 3 variables namely Attitude (Y1), Subjective Norms (X2) and Perceived Behavioral Control (X2), the most influential is Perceived Behavioral Control while the smallest influence is Subjective Norms. From this it can be understood that to bring up the Intention to share knowledge at Siti Khadijah Hospital, the role of perceived behavioral control is needed. Meanwhile, on the other hand, it can be seen that in the present condition the role and influence of Subjective Norms are still very small so that they can be pursued to be improved, or it can be concluded that currently Subjective Norms have not significantly affected the Intention of Knowledge Sharing. 


\section{Implementation of Analysis Results into Feature os Knowledge Management System} Attitude.

After getting the results of the analysis of each TPB variable and indicator, a feature will be presented that presents each variable of each feature.

Table 6. Features

\begin{tabular}{|c|c|c|c|c|}
\hline Code & Variable & Feature & Service & Description \\
\hline $\begin{array}{l}\text { Y1.1 } \\
\text { Y1.2 } \\
\text { Y2.1 } \\
\text { Y2.2 } \\
\text { Y2.3 }\end{array}$ & $\begin{array}{l}\text { Attitude } \\
\text { Intention }\end{array}$ & Share Know-ledge & \multirow{5}{*}{$\begin{array}{l}\text { Knowledge } \\
\text { Sharing }\end{array}$} & Feature to share knowledge \\
\hline $\mathrm{X} 2.1$ & Perceived Behavioral Control & Upload File & & $\begin{array}{l}\text { Feature to upload file such as } \\
\text { document and photo }\end{array}$ \\
\hline $\mathrm{X} 2.1$ & Perceived Behavioral Control & Text & & Feature to write knowledge \\
\hline $\begin{array}{l}\text { Y1.3 } \\
\text { Y2.5 }\end{array}$ & $\begin{array}{l}\text { Attitude } \\
\text { Intention }\end{array}$ & View & & $\begin{array}{c}\text { Feature to view uploaded } \\
\text { knowledge }\end{array}$ \\
\hline Y1.6 & Intention & Timeline & & Feature to show what others do \\
\hline Y1.7 & Attitude & Comment & \multirow[t]{2}{*}{ Feedback } & $\begin{array}{l}\text { Feature to give comment to } \\
\text { uploaded knowledge }\end{array}$ \\
\hline $\begin{array}{l}\mathrm{Y} 1.7 \\
\mathrm{X} 2.3\end{array}$ & $\begin{array}{c}\text { Attitude } \\
\text { Perceived Behavioral Control }\end{array}$ & Like & & $\begin{array}{l}\text { Feature to like uploaded } \\
\text { knowledge }\end{array}$ \\
\hline Y1.5 & Attitude & Search & \multirow[t]{2}{*}{$\begin{array}{l}\text { Search Know- } \\
\quad \text { ledge }\end{array}$} & Feature to search knowledge \\
\hline Y1.4 & Attitude & Trend-ing & & $\begin{array}{l}\text { Feature to see the most search } \\
\text { keyword }\end{array}$ \\
\hline $\mathrm{X} 2.4$ & Perceived Behavioral Control & Point & \multirow[t]{2}{*}{ Reward } & Feature to see member's activity \\
\hline $\mathrm{X} 2.4$ & Perceived Behavioral Control & Redeem Reward & & $\begin{array}{l}\text { Feature to change point into } \\
\text { reward }\end{array}$ \\
\hline $\mathrm{X} 2.2$ & Perceived Behavioral Control & Menu & Menu & $\begin{array}{c}\text { Features to make it easier for } \\
\text { users to choose the desired menu }\end{array}$ \\
\hline
\end{tabular}

\section{CONCLUSION}

Based on the result of the reseach, we can conclude that : 1. Nurse's attitude toward intention to knowledge sharing have a good influence. It can be conclude that role and influence of attitudes possessed by each individual determine the success of intention to share knowledge.

2. Nurse's attention to knowledge sharing in Siti Khadijah Hospital Palembang did not influence by subjective norm. So it is necessary to evaluate it, so that the subjective norm can have an impact and influence in the intention to knowledge sharing.

3. Perceived Behavioral Control have the biggest influence toward intention to knowledge sharing in Siti Khadijah Hospital Palembang. Intention to share knowledge requires a behavioral control, such as an award obtained from other members and from the organization itself.

4. We managed to identify 12 features needed by the user to bring up the intention to share knowledge, including the Share Knowledge feature, Upload Files, Text, View, Timeline, Comments, Likes, Search, Trending, Points, Reedem Reward, and Menu.

\section{REFERENCES}

[1] Ghozali, I. (2014). Structural equation modeling: Metode alternatif dengan partial least square (pls) (IV). Badan Penerbit Universitas Diponegoro.

[2] Gjesdal, K., Dysvik, E., \& Furnes, B. (2019). Nurses' experiences with health care in pain clinics: A qualitative study. International Journal of Nursing Sciences. https://doi.org/10.1016/J.IJNSS.2019.03.005

[3] Hajia, A. M., Mohammed, F. A. K., Al-Saqer, M. A., Kamel, M. I., \& El-Shazly, M. K. (2011).

Knowledge, attitude and practice of nurses toward peak expiratory flow meter in primary health care centers in Kuwait. Alexandria Journal of Medicine, 47(3), 255260. https://doi.org/10.1016/J.AJME.2011.08.005

[4] Harrison, R., Lawton, R., Perlo, J., Gardner, P., Armitage, G., \& Shapiro, J. (2015). Emotion and Coping in the Aftermath of Medical Error. Journal of 
knowledge sharing contributes to organizational performance: Using the fsQCA approach. Journal of Business Research, 94, 313-319.

https://doi.org/10.1016/J.JBUSRES.2018.02.027

[5] Ipe, M. (2003). Knowledge Sharing in Organizations: A Conceptual Framework. Human Resource Development Review, 2(4), 337-359. https://doi.org/10.1177/1534484303257985

[6] Jambak, M. I. (2017). Faktor-Faktor yang Mempengaruhi Perilaku Berbagi Pengetahuan Diantara Mahasiswa Baru Fakultas Ilmu Komputer UNSRI. KNTIA, 4(1).

[7] Kathiravelu, S. R., Mansor, N. N. A., T.Ramayah, \& Idris, N. (2014). Why Organisational Culture Drives Knowledge Sharing? Procedia - Social and Behavioral Sciences, 129, 119-126. https://doi.org/10.1016/J.SBSPRO.2014.03.656

[8] King, W. R. (2006). Knowledge Sharing. In Encyclopedia of Knowledge Management (pp. 493498). IGI Global. https://doi.org/10.4018/978-1-59140573-3.ch064

[9] Leal, C., Cunha, S., \& Couto, I. (2017). Knowledge sharing at the construction sector facilitators and inhibitors. Procedia Computer Science, 121, 998-1005.

https://doi.org/10.1016/J.PROCS.2017.11.129

[10] Lee, H. S., \& Hong, S. A. (2014). Factors Affecting Hospital Employees' Knowledge Sharing Intention and Behavior, and Innovation Behavior. Osong Public Health and Research Perspectives, 5(3), 148-155. https://doi.org/10.1016/J.PHRP.2014.04.006

[11] Liebowitz, J. (2001). Knowledge management: learning from knowledge engineering. CRC Press.

[12] Lin, M.-H., Wu, C.-Y., \& Hsu, H.-C. (2019). Exploring the experiences of cultural competence among clinical nurses in Taiwan. Applied Nursing Research, 45, 6-11. https://doi.org/10.1016/J.APNR.2018.11.001

[13] Oyemomi, O., Liu, S., Neaga, I., Chen, H., \& Nakpodia, F. (2019). How cultural impact on
[14] Phetlhu, D. R., Bimerew, M., Marie-Modeste, R. R., Naidoo, M., \& Igumbor, J. (2018). Nurses' Knowledge of Tuberculosis, HIV, and Integrated HIV/TB Care Policies in Rural Western Cape, South Africa. Journal of the Association of Nurses in AIDS Care, 29(6), 876-886.

https://doi.org/10.1016/J.JANA.2018.05.008

[15] Ryu, S., Ho, S. H., \& Han, I. (2003).

Knowledge sharing behavior of physicians in hospitals. Expert Systems with Applications, 25(1), 113-122. https://doi.org/10.1016/S0957-4174(03)00011-3

[16] Šajeva, S. (2014). Encouraging Knowledge Sharing among Employees: How Reward Matters. Procedia - Social and Behavioral Sciences, 156, 130134. https://doi.org/10.1016/J.SBSPRO.2014.11.134

[17] Samad, S. (2018). Theory of planned behavior and knowledge sharing among nurses in patient computer management system: The role of distributive justice. Management Science Letters, 427-436. https://doi.org/10.5267/j.msl.2018.4.003

[18] Shaari, R., Bakri, N., \& Mannan, A. A. (2015). Antecedents of Knowledge Sharing Behavior among Nurses: Towards Research Agenda. Procedia Social and Behavioral Sciences, 171, 635-641. https://doi.org/10.1016/J.SBSPRO.2015.01.171

[19] Sundean, L. J., White, K. R., Thompson, L. S., \& Prybil, L. D. (2019). Governance education for nurses: Preparing nurses for the future. Journal of Professional Nursing. https://doi.org/10.1016/J.PROFNURS.2019.04.001

[20] Trivellas, P., Akrivouli, Z., Tsifora, E., \& Tsoutsa, P. (2015). The Impact of Knowledge Sharing Culture on Job Satisfaction in Accounting Firms. The Mediating Effect of General Competencies. Procedia Economics and Finance, 19, 238-247. https://doi.org/10.1016/S2212-5671(15)00025- 